\title{
Pembaharuan Standar Prosedure Operasi Pengaturan (SOP) Pelayanan Pendaftaran Peralihan Hak Milik Atas Tanah Karena Hibah Wasiat Berdasarkan Alat Bukti Peralihan Hak
}

\author{
Upik Hamidah
}

Dosen Bagian Hukum Administrasi Negara FH Universitas Lampung

\begin{abstract}
Abstrak
Tujuan penelitian ini adalah untuk mengetahui bagaimana SPOPP pendaftaran peralihan hak karena hibah wasiat berdasarkan alat bukti peralihan hak. Metode penelitian yang digunakan adalah yuridis empiris yang dilakukan dengan studi lapangan dan studi pustaka. Hasil penelitian menunjukan bahwa dengan adanya pembaharuan dalam bidang pendaftaran tanah melalui PP Nomor 24 tahun 1997 tentang Pendaftaran Tanah, Peraturan Kepala BPN Nomor 3 tahun 1997 dan Peraturan Kepala BPN Nomor 1 tahun 2005 tentang SPOPP di lingkungan BPN, sebagai alternatif pilihan alat bukti peralihan hak yang dapat dipakai sebagai dasar dalam pendaftaran peralihan hak karena hibah wasiat, mengakibatkan tidak adanya kepastian SPOPP pendaftaran peralihan hak karena hibah wasiat. Disarankan sebagai upaya untuk menunjang pembaharuan pembangunan dan pembinaan hukum dikalangan masyarakat perlu ada Standar Prosedure Operasi Pengaturan dan Pelayanan yang pasti dan jelas tentang pendaftaran peralihan hak atas tanah karena hibah wasiat.
\end{abstract}

Kata kunci : peralihan hak, Standar Prosedure Operasi Pengaturan dan Pelayanan, dan hibah wasiat

\section{PENDAHULUAN}

Pada zaman hukum agraria lama sebelum berlakunya Undang Undang Nomor 5 tahun 1960 tentang Peraturan Dasar Pokok Pokok Agraria, yang lebih dikenal dengan istilah Undang Undang Pokok Agraria (UUPA), mengenai peralihan hak milik cukup dilakukan dihadapan kepala desa/kepala suku secara dibawah tangan. Akan tetapi setelah lahirnya UUPA mengenai pemindahan hak milik diatur dalam Pasal 26 ayat (1) yang menentukan bahwa jual beli, penukaran, penghibahan, pemberian dengan wasiat, pemberian menurut hukum adat dan perbuatan perbuatan lainnya yang dimaksudkan untuk memindahkan hak milik serta pengawasannya diatur dengan peraturan pemerintah. Walaupun tujuan dari diadakannya ketentuan tersebut, adalah larangan pengasingan tanah hak milik oleh Warga Negara Indonesia kepada Warga Negara Asing, akan tetapi dari ketentuan tersebut, diketahui bahwa salah satu bentuk pemindahan hak milik dapat melalui cara pemberian dengan wasiat, yang di dalam hukum adat dikenal dengan istilah hibah wasiat. Sedangkan dalam hukum perdata memakai istilah pewarisan secara testamenter (berdasarkan wasiat). Walaupun dalam UUPA menggunakan istilah pemberian dengan wasiat, namun karena menurut Pasal 5 UUPA 
bahwa hukum agraria yang berlaku atas bumi, air dan ruang angkasa ialah hukum adat, maka pemberian dengan wasiat sama artinya dengan hibah wasiat dan dapat dijadikan sebagai salah satu cara untuk memperoleh hak milik. Dalam hukum adat dan hukum islam bisa dilakukan secara lisan, walaupun ada juga dilakukan secara tertulis, sedangkan dalam hukum barat harus dilakukan secara tertulis yang terkenal dengan nama legaat. Pemberian hak milik karena hibah wasiat secara tertulis dapat diberikan dengan akta di bawah tangan atau akta notaris.

Berbeda dengan cara memperoleh hak milik melalui hibah, pemberian dengan wasiat atau hibah wasiat ini merupakan suatu pemberian hak atas tanah pada waktu pemiliknya masih hidup, tetapi pelaksanaan peralihan hak nya setelah yang memberi itu meninggal dunia, jadi haknya baru beralih setelah pemberi hibah wasiat tersebut meninggal dunia, selama pemberi hibah wasiat itu masih hidup ia berhak menarik kembali atau membatalkan pemberiannya.

Oleh karena cara memperoleh hak milik dengan hibah wasiat atau pemberian dengan wasiat ini, haknya baru beralih setelah pemberi hibah wasiat meninggal dunia, maka dapat dikatakan hibah wasiat tersebut merupakan masalah pewarisan, peralihan haknya terjadi karena hukum, pada saat pemberi hak yang bersangkutan meninggal dunia, sehingga peralihan hak milik melalui hibah wasiat tidak diperlukan akta hibah wasiat dari PPAT, akan tetapi peralihan haknya itu tetap harus didaftarkan dalam rangka kepastian hukum dan perlindungan hukum hak atas tanah ahli waris atau penerima haknya serta demi tertib administrasi pertanahan.

Tidak ada akta hibah wasiat yang dilaksanakan dihadapan PPAT, hal ini dapat terlihat dari Pasal 95 ayat (1) Peraturan Menteri Negara Agraria/Keputusan Kepala BPN nomor 3 tahun 1997 tentang Ketentuan Pelaksanaan Peraturan Pemerintah nomor 24 tahun 1997 tentang Pendaftaran Tanah yang menentukan bahwa jenis akta yang dibuat oleh PPAT adalah :

a. Akta jual beli

b. Akta tukar menukar

c. Akta hibah

d. Akta pemasukan ke dalam perusahaan

e. Akta pembagian hak bersama

f. Akta pemberian hak tanggungan

g. Akta pemberian HGB atas tanah hak milik

h. Akta pemberian hak pakai atas tanah hak milik.

Berdasarkan uraian di atas bahwa di salah satu pihak tidak ada jenis akta PPAT mengenai hibah wasiat, dilain pihak peralihan hak milik itu harus didaftarkan, seperti ditegas dalam Pasal 37 ayat (1) Peraturan Pemerintah nomor 24 tahun 1997 menentukan bahwa peralihan hak atas tanah dan hak milik atas satuan rumah susun melalui jual beli, tukar menukar, hibah, pemasukan dalam perusahaan dan perbuatan hukum pemindahan hak lainnya, kecuali pemindahan hak melalui lelang dapat didaftarkan jika dibuktikan dengan akta yang dibuat oleh PPAT yang berwenang menurut ketentuan peraturan perundang undangan yang berlaku. Pasal ini menunjukan bahwa hanya akta yang dibuat dihadapan PPAT yang dapat dijadikan dasar atau alat bukti pemindahan hak atas tanah. 
Sehubungan dengan hal tersebut di atas, Pasal 112 Ayat (3) Permeneg Agraria/Keputusan Kepala BPN nomor 3 tahun 1997 menentukan bahwa untuk pendaftaran peralihan hak atas tanah karena pewarisan yang disertai dengan hibah wasiat, jika hak atas tanah yang dihibahkan sudah tertentu, maka pendaftaran peralihan haknya dapat dilakukan atas permohonan penerima hibah wasiat, jika dibukti dengan putusan pengadilan atau penetapan hakim/ketua pengadilan mengenai pembagian harta waris yang memuat penunjukan hak atas tanah yang bersangkutan sebagai telah dihibah wasiatkan kepada pemohon atau akta PPAT mengenai hibah yang dilakukan oleh pelaksana wasiat atas nama pemberi hibah wasiat sebagai pelaksanaan dari wasiat yang dikuasakan pelaksanaannya kepada pelaksana wasiat tersebut atau akta pembagian waris yang memuat penunjukan hak atas tanah yang bersangkutan sebagai telah dihibah wasiatkan kepada pemohon.

Akan tetapi tidak ada ketegasan pengaturan tentang penentuan alat bukti peralihan hak karena hibah wasiat yang dapat dipakai sebagai dasar pendaftaran peralihan hak karena hibah wasiat. Ketegasan mengenai hal ini dirasakan sangat perlu sebab ketidak jelasan pelaksanaan peraturan perundang undangan dapat menimbulkan salah penafsiran dan kadang kala menimbulkan kesulitan dan kerugian bagi para pihak yang berkepentingan.

Meskipun di Indonesia jarang sekali ada masyarakat melakukan pemberian hak milik atas tanahnya dengan cara hibah wasiat, akan tetapi harus ada kejelasan pengaturan yang dapat dijadikan pedoman dalam melaksanakan pendaftaran peralihan hak milik atas tanah karena hibah wasiat. Dalam praktek pendaftaran peralihan hak milik atas tanah karena hibah wasiat, sudah dapat dilaksanakan walaupun alat bukti pemberian hak milik hanya dengan akta di bawah tangan. Oleh karena itu penulis tertarik untuk mengetahui dan mengkaji tentang pembaharuan pendaftaran peralihan hak milik atas tanah karena hibah wasiat berdasarkan alat bukti peralihan hak, baik alat bukti peralihan hak berdasarkan akta PPAT mengenai hibah atau akta pembagian warisan.

Berdasarkan uraian di atas, maka yang menjadi permasalahan adalah Bagaimanakah pembaharuan SPOPP pendaftaran peralihan hak milik atas tanah karena hibah wasiat berdasarkan alat bukti peralihan hak?

\section{PEMBAHASAN}

\subsection{Hibah wasiat antara pemindahan hak dan pewarisan}

Terhadap peralihan hak terkandung dua pengertian, yaitu beralih dan dialihkan. Beralih adalah suatu perbuatan peralihan hak yang terjadi dengan tidak sengaja melakukan suatu perbuatan tertentu, tetapi terjadi karena hukum, yaitu jika pemegang suatu hak atas tanah meninggal dunia, maka hak atas tanahnya beralih dengan sendirinya menjadi hak milik ahli warisnya. Peralihan hak dengan cara demikian disebut dengan cara pewarisan. Peralihan hak dengan cara pewarisan kepada ahli waris pengaturannya tentang siapa siapa yang termasuk ahli waris, berapa besar bagian masing masing dan bagaimana cara 
pembagiannya diatur oleh hukum waris almarhum atau pewaris. Tetapi mengenai pengaturan penguasaan tanah warisan dan pembuktian peralihan hak diatur oleh hukum tanah nasional. Memperhatikan terjadinya peralihan hak dengan cara pewarisan tersebut, bahwa pada saat pewaris meninggal dunia, jika dikaitkan dengan pengertian dari hibah wasiat adalah suatu pemberian yang dinyatakan ketika yang memberi itu masih hidup tetapi pelaksanaan peralihan haknya setelah yang memberi itu meninggal dunia, maka berarti jika dilihat dari waktu pelaksanaan peralihan haknya hibah wasiat itu termasuk peralihan hak karena pewarisan.

Sedangkan pengertian dialihkan adalah suatu perbuatan peralihan hak yang terjadi dengan sengaja supaya hak tersebut terlepas dari pemegangnya yang semula dan menjadi hak pihak lain, atau dengan kata lain bahwa peralihan hak itu terjadi dengan melalui suatu perbuatan hukum tertentu. Peralihan hak demikian disebut dengan pemindahan hak. Jika dikaitkan dengan pengertian hibah wasiat, yang mana pemberian haknya dilakukan dengan sengaja oleh pemilik tanah ketika masih hidup, maka dapat dikatakan bahwa hibah wasiat atau pemberian dengan wasiat merupakan pemindahan hak.

Dari uraian di atas terlihat bahwa hibah wasiat, jika dilihat dari waktu peralihan haknya yaitu ketika pemberi wasiat sudah meninggal dunia, maka tergolong dalam peralihan hak karena pewarisan. Hibah wasiat tidak perlu dibuktikan dengan Akta PPAT, tetapi wajib di daftarkan seperti pendaftaran pewarisan (K. Wantjik Saleh, 1977: 36)
Sehubungan dengan peralihan hak karena pewarisan ditentukan dalam Pasal 42 Peraturan Pemerintah Nomor 24 tahun 1997 tentang Pendaftaran Tanah, yang pada intinya bahwa jika penerima waris hanya satu orang, maka pembuktian peralihan haknya adalah surat tanda bukti sebagai ahli waris. Pendaftaran peralihan haknya disertai dengan surat keterangan kematian pewaris dan sertifikat bagi tanah sudah pernah didaftar. Jika belum pernah didaftar maka surat bukti hak atau surat keterangan kepala desa/kelurahan yang menyatakan bahwa yang bersangkutan menguasai bidang tanah tersebut dan surat keterangan yang menyatakan bahwa bidang tanah yang bersangkutan belum bersertifikat dari Kantor Pertanahan. Akan tetapi jika penerima waris lebih dari satu orang, maka pembuktian peralihan haknya selain harus ada surat tanda bukti sebagai ahli waris harus ada akta pembagian warisan, namun apabila belum ada akta pembagian warisan dapat didaftar peralihan haknya sebagai hak bersama.

Ketentuan Pasal 42 PP nomor 24 tahun 1997 tentang Pendaftaran Tanah tersebut menunjukan bahwa alat bukti peralihan hak karena pewarisan tidak perlu harus dibuktikan dengan akta Pejabat Pembuat Akta Tanah, Akan tetapi dalam Pasal 95 Peraturan Menteri Negara Agraria/Kepala BPN nomor 3 tahun 1997 menentukan adanya akta pembagian hak bersama yang dibuat oleh PPAT, walaupun dalam praktek untuk pendaftaran peralihan hak karena pewarisan cukup hanya dengan akta pembagian warisan yang dibuat dan telah disetujui bersama oleh para ahli waris yang bersangkutan dengan disaksikan oleh 
2 (dua) orang saksi atau akta notaries. Alat bukti peralihan hak karena pewarisan jarang sekali sampai menggunakan akta pembagian hak bersama dari Pejabat Pembuat Akta Tanah.

Jika memperhatikan ketentuan Pasal 112 ayat (1) Peraturan Menteri Negara Agaria/Keputusan Kepala BPN nomor 3 tahun 1997 peralihan hak karena hibah wasiat termasuk peralihan hak karena pewarisan yang harus di daftarkan.

Tetapi jika dilihat dari waktu pemberian haknya yang disengaja dilakukan oleh pemberi wasiat ketika masih hidup, maka tergolong peralihan hak karena pemindahan hak. Berkaitan dengan pemindahan hak Pasal 37 (1) PP Nomor 24 tahun 1997 menentukan bahwa setiap pemindahan hak kecuali lelang hanya dapat didaftar jika dibuktikan dengan akta yang dibuat oleh PPAT yang berwenang.

Jenis akta PPAT sebagai alat bukti pemindahan hak diatur dalam Pasal 95 Peraturan Menteri Negara Agraria/ Kepala Badan Pertanahan Nasional Nomor 3 tahun 1997 tentang Ketentuan Pelaksana Peraturan Pemerintah Nomor 24 tahun 1997, tetapi tidak ada jenis akta PPAT mengenai hibah wasiat. Dengan tidak adanya jenis akta PPAT mengenai hibah wasiat menunjukan bahwa peralihan hak karena hibah wasiat tidak termasuk sebagai perbuatan hukum pemindahan hak. Akan tetapi Pasal 112 ayat (1) angka 3 huruf a Peraturan Kepala BPN Nomor 3 tahun 1997 menentukan bahwa akta PPAT mengenai hibah yang dilakukan oleh pelaksana wasiat atas nama pemberi hibah wasiat sebagai pelaksanaan dari wasiat yang dikuasakan pelaksanaannya kepada pelaksana wasiat, dapat dipakai sebagai salah satu syarat atau sebagai alat bukti peralihan hak karena hibah wasiat.

\subsection{Pendaftaran peralihan hak atas tanah karena hibah wasiat}

a. Penentuan alat bukti peralihan hak

Penentuan alat bukti peralihan hak karena hibah wasiat, yang akan dipakai sebagai dasar dalam pendaftaran peralihan hak, sangat tergantung pada penilaian Kepala Kantor Pertanahan akan kadar nilai kebenaran alat bukti pemberian hak yang ada, baik berupa akta di bawah tangan maupun akta hibah wasiat yang dibuat oleh dan dihadapan notaris.

Jika akta hibah wasiat yang dijadikan alat bukti peralihan hak baik yang dibuat oleh dan dihadapan notaries maupun akta hibah wasiat dibawah tangan, menurut penilaian Kepala Kantor Pertanahan kebenarannya tidak diragukan, maka pendaftaran peralihan hak dilakukan melalui prosedure pewarisan, yang berarti dasar pendaftaran peralihan haknya adalah akta pembagian warisan,yang diperkuat dengan surat keterangan waris dan surat pernyataan ahli waris. Dalam hal ini fungsi Akta hibah wasiat dari notaris atau akta hibah dibawah tangan hanya sebagai petunjuk yang memperkuat penetapan subyek dan obyek hak atas tanah yang dihibah wasiatkan. Demikian juga akta hibah wasiat yang hanya dibuat di bawah tangan, jika memenuhi syarat dan menurut Kepala Kantor Pertanahan nilai kebenarannya tidak diragukan dapat dipakai sebagai dasar 
pendaftaran peralihan hak karena hibah wasiat. Dengan adanya kebebasan Kepala Kantor Pertanahan dalam penentuan alat bukti peralihan hak dengan cara terlebih dahulu menilai kebenaran alat bukti pemberian hak adalah untuk mempermudah proses pendaftaran hak sesuai dengan asas sederhana dan terjangkau dalam pendaftaran tanah.

Menurut penulis jika alat bukti peralihan hak yang dipakai sebagai dasar dalam pendaftaran peralihan hak itu berupa akta pembagian warisan, berarti yang digunakan dalam pendaftaran peralihan hak karena hibah wasiat adalah SPOPP pewarisan. Akan tetapi sebaliknya jika menurut penilaian Kepala kantor Pertanahan kebenaran akta hibah wasiat baik di bawah tangan atau akta dibuat oleh dan dihadapan notaris tingkat kebenarannya meragukan atau tidak memenuhi syarat yang sudah ditentukan, maka pendaftaran peralihan hak atas tanah karena hibah wasiat dilaksanakan berdasarkan Akta PPAT mengenai hibah yang dilakukan oleh pelaksana wasiat atas nama pemberi hibah wasiat sebagai pelaksanaan dari wasiat yang dikuasakan pelaksanaannya kepada pelaksana wasiat.

Akan tetapi jika alat bukti peralihan hak yang dipakai sebagai dasar pendaftaran peralihan haknya itu berupa akta PPAT mengenai hibah, berarti yang digunakan dalam pendaftaran peralihan hak karena hibah wasiat tersebut adalah SPOPP pemindahan hak yaitu SPOPP hibah. Walaupun jika berdasarkan waktu pelaksanaan peralihan haknya, yaitu terjadi setelah pewaris atau pemberi wasiat meninggal dunia, maka baik alat bukti peralihan haknya berupa akta pembagian warisan maupun berupa akta PPAT terhadap peralihan hak karena hibah wasiat termasuk peralihan hak karena pewarisan.

b. Persyaratan pendaftaran peralihan hak karena hibah wasiat

Dari uraian di atas dapat diketahui bahwa tidak semua peralihan hak atas tanah harus dibuktikan dengan akta PPAT. Terjadinya peralihan hak atas tanah karena hibah wasiat yaitu setelah pemberi hibah wasiat meninggal dunia, akan tetapi untuk mendapatkan kepastian hukum atas pemilikannya dan mempunyai daya pembuktian yang lebih kuat dan luas masih perlu dilakukan pendaftaran peralihan hak.

Berdasarkan hasil penelitian di Kota Bandar Lampung dalam melakukan pendaftaran peralihan hak karena hibah wasiat, jika pemohon sudah memiliki akta hibah wasiat dari notaries dan tanah yang dihibah wasiatkan sudah bersertifikat, maka pemohon pendaftaran peralihan hak karena hibah wasiat harus menyerahkan syarat syarat sebagai berikut:
a) Surat permohonan
b) Sertifikat asli
c) Akta hibah wasiat yang asli atau yang dilegalisir notaries
d) Surat keterangan kematian pemberi hibah wasiat
e) Asli surat keterangan waris dengan berpedoman pada 4 kategori :

1. Golongan keturunan Tionghoa dibuat notaries

2. Golongan timur asing yang dibuat oleh Balai harta peninggalan atau pengadilan negeri atau pengadilan agama. 
3. Warga negara Indonesia Asli dibuat oleh para ahli waris dengan disaksikan oleh 2 (dua) orang saksi yang dikuatkan oleh lurah dan camat.

f) Surat pernyataan dari para ahli waris

g) Surat kuasa jika yang mengajukan permohonan bukan ahli waris atau penerima hibah wasiat yang bersangkutan

h) Identitas penerima hibah wasiat

i) SPPT PBB tahun berjalan

j) Surat Setoran BPHTB apabila memenuhi syarat terkena kewajiban membayar BPHTB.

Demikian juga peralihan hak atas tanah karena hibah wasiat yang hanya berdasarkan akta dibawah tangan dapat dilakukan pendaftarannya, tetapi harus memperhatikan hal hal sebagai berikut :

a) Memeriksa dengan teliti akta hibah wasiat yang dibuat dibawah tangan tersebut benar atau tidak dan tidak ada kejanggalan kejanggalan yang meragukan.

b) Akta hibah wasiat itu memuat saksi saksi yang berkompeten misalnya keluarga sedarah dan saksi saksi tersebut dapat dihadirkan apabila diperlukan

c) Akta hibah wasiat itu harus menunjuk pelaksana wasiat

d) Diketahui oleh lurah dan camat setempat

e) Memeriksa identitas dari penerima hibah wasiat dengan teliti

f) Ada surat pernyataan dari ahli waris yang menyatakan bahwa ahli waris menerima dan melaksanakan hibah wasiat tersebut. g) Seandainya meragukan, maka dibuatkan akta hibah dihadapan PPAT dengan pelaksana wasiat sebagai pemberi hibah.

Adapun syarat syarat yang diperlukan dalam pembuatan akta hibah di hadapan PPAT ditentukan dalam Pasal 103 Permeneg Agraria/Kepala BPN nomor 3 tahun 1997 yaitu diserahkan juga akta hibah wasiat, surat keterangan kematian dan surat keterangan waris kepada PPAT sebagai dasar pembuatan akta hibah. Baik pelaksana wasiat selaku pemberi hibah dan penerima hibah wasiat selaku penerima hibah harus hadir di hadapan PPAT untuk menandatangani akta hibah PPAT yang dibuat tersebut. Dalam praktek diperlukannya syarat akta hibah yang dibuat oleh PPAT dalam pendaftaran peralihan hak karena hibah wasiat, apabila alat bukti akta hibah wasiat yang ada baik yang dibuat notaries atau dibawah tangan itu dipandang nilai kebenarannya meragukan. Apabila tidak meragukan, maka akta hibah wasiat yang dibuat oleh notaries berfungsi untuk menetapkan subyek haknya saja, sedangkan yang memperkuat akta tersebut adalah surat keterangan waris dan surat pernyataan dari ahli waris.

Menurut penulis diambil langkah kebijakan oleh Kepala Kantor Pertanahan dalam pendaftaran peralihan hak karena hibah wasiat demikian, menunjuk Pasal 37 ayat (2) Peraturan Pemerintah nomor 24 tahun 1997 yang menentukan bahwa dalam keadaan tertentu sebagaimana yang ditentukan oleh menteri, Kepala Kantor Pertanahan dapat mendaftar pemindahan hak atas bidang tanah hak milik yang dilakukan di antara perorangan WNI yang dibuktikan 
dengan akta yang tidak dibuat oleh PPAT. Hal ini jika menurut Kepala Kantor Pertanahan tersebut kadar kebenarannya tidak diragukan untuk mendaftar pemindahan hak yang bersangkutan.

Jika alat bukti pemberian hak karena hibah wasiat, baik akta di bawah tangan atau akta notaris yang nilai kebenarannya diragukan, kemudian disyaratkan membuat akta hibah dari PPAT, prosedure demikian berarti tidak mencerminkan asas asas pendaftaran tanah, terutama asas sederhana dan terjangkau yang bertujuan memberikan pelayanan yang cepat dengan prosedure tidak berbelit belit, sehingga tidak banyak memakan waktu dan biaya yang besar, karena membuat akta hibah dari PPAT tentunya akan memperpanjang waktu dan menambah biaya.

Jadi fungsi dari akta hibah wasiat yang dibuat dihadapan notaries disini hanya untuk menetapkan subyek haknya saja, sedangkan yang memperkuat akta hibah wasiat tersebut adalah surat keterangan waris dan surat pernyataan ahli waris. Memperhatikan syarat syarat pendaftaran peralihan hak karena hibah wasiat di Kota Bandar Lampung seperti tersebut di atas berarti peralihan hak atas tanah karena hibah wasiat merupakan perbuatan hukum pewarisan bukan pemindahan hak.

Fungsi akta hibah wasiat yang dibuat oleh notaris hanya sebagai penunjuk subyek dan obyek dalam hibah wasiat, tidak dapat langsung dipakai sebagai alat bukti peralihan hak yang dapat dipakai sebagai dasar dalam pendaftaran peralihan hak karena hibah wasiat, walaupun Pasal 115 Undang Undang nomor 34 tahun
2004 tentang Notaris, menghendaki notaris berhak membuat akta akta tanah tertentu. Akan tetapi Badan Pertanahan Nasional menolak atau tidak menerina akta notaris dipakai sebagai dasar dalam melakukan pendaftaran peralihan hak.

c. Tata cara pendaftaran peralihan hak atas tanah karena hibah wasiat

Pelaksanaan pendaftaran tanah menurut Peraturan Pemerintah nomor 24 tahun 1997 meliputi kegiatan pendaftaran tanah untuk pertamakali dan pemeliharaan data pendaftaran tanah. Kegiatan pendaftaran tanah untuk pertamakali meliputi pengumpulan data dan pengolahan data fisik, pembuktian hak dan pembukuannya, penerbitan sertifikat, penyajian data fisik dan data yuridis, penyimpanan daftar umum dan dokumen. Sedangkan kegiatan pemeliharaan data pendaftaran tanah meliputi pendaftaran peralihan dan pembebanan serta pendaftaran perubahan data pendaftaran tanah lainnya.

Dari ketentuan di atas pendaftaran hak atas tanah karena hibah wasiat dapat termasuk dalam kegiatan pemeliharaan data pendaftaran tanah jika tanah tersebut sebelumnya sudah terdaftar atau telah mempunyai sertifikat, tetapi jika belum pernah terdaftar atau bersertifikat maka pelaksanaan pendaftaran tanahnya dengan cara pendaftaran tanah untuk pertamakali yang pelaksanaannya dapat secara sistimatik ataupun secara sporadic. Kegiatan pemeliharaan data pendaftaran tanah dilakukan apabila terjadi perubahan pada data fisik atau 
data yuridis obyek pendaftaran tanah yang telah terdaftar.

$$
\text { Pencatatan pendaftaran }
$$

peralihan hak karena pewarisan yang disertai dengan hibah wasiat dalam daftar daftar tanah dilakukan sesuai atau sama dengan pendaftaran peralihan hak karena pemindahan hak.

Pasal 105 ayat (1) Peraturan Menteri Negara Agraria/Kepala BPN nomor 3 tahun 1997 menentukan bahwa :

1. Pencatatan peralihan hak dalam buku tanah, sertifikat dan daftar lainnya dilakukan sebagai berikut

a. Nama pemegang hak lama didalam buku tanah dicoret dengan tinta hitam dan dibubuhi paraf Kepala Kantor Pertanahan atau Pejabat yang ditunjuk.

b. Nama atau nama nama pemegang hak yang baru ditulis pada halaman dan kolom yang ada dalam buku tanahnya dengan dibubuhi tanggal pencatatan dan besarnya bagian setiap pemegang hak dalam hal penerima hak beberapa orang dan besarnya bagian ditentukan.

c. Kemudian ditanda tangani oleh Kepala Kantor pertanahan atau Pejabat yang ditunjuk dan cap dinas Kantor Pertanahan.

d. Pencatatan seperti tersebut pada huruf $a$ dan $b$ juga dilakukan pada sertifikat hak yang bersangkutan dan daftar daftar umum lainnya yang memuat nama pemegang hak lama.

e. Nomor hak dan identitas lainnya dari tanah yang dialihkan dicoret dari daftar nama pemegang hak lama dan nomor hak dan identitas tersebut dituliskan pada daftar nama penerima hak.

2. Apabila pemegang hak baru lebih dari satu orang dan hak tersebut dimiliki bersama, maka untuk masing masing pemegang hak dibuatkan daftar nama dan dibawah nomor hak atas tanahnya diberi garis dengan tinta hitam.

3. Apabila peralihan hak hanya mengenai sebagian dari sesuatu hak atas tanah sehingga hak atas tanah itu menjadi kepunyaan bersama pemegang hak lama dan pemegang hak baru, maka pendaftarannya dilakukan dengan menuliskan besarnya bagian pemegang lama dibelakang namanya dan menuliskan nama pemegang hak yang baru beserta besarnya bagian yang diperolehnya dalam halaman perubahan yang disediakan.

4. Sertifikat hak yang dialihkan diserahkan kepada pemegang hak baru atau kuasanya.

Berdasarkan hasil penelitian bahwa tata cara pendaftaran peralihan hak karena hibah wasiat pertama tama pemohon mengajukan permohonan pendaftaran peralihan hak atas tanah dengan melampirkan persyaratan persyaratan yang sudah ditentukan seperti tersebut di atas.

Setelah syarat syarat tersebut diserahkan kepada petugas loket, maka permohonan peralihan hak atas tanah tersebut akan diterima dan diperiksa oleh petugas dan akan dibuatkan Surat Perintah Setor (SPS) yang kemudian dicatat pada Daftar Isian 305 yaitu daftar setoran keuangan kepada Bendahara 
penerima, selanjutnya akan dilakukan pencatatan pada daftar isian 301 yaitu daftar tentang permohonan pendaftaran peralihan hak atas tanah. Setelah dicatat dalam daftar isian 301 permohonan peralihan hak atas tanah tersebut, maka dicatat pada daftar isian 204 yaitu daftar tentang kepemilikan tanah yaitu daftar yang berisikan tentang banyaknya bidang tanah yang dimiliki, hal ini dilakukan karena menurut ketentuan setiap orang tidak boleh mempunyai lebih dari 5 (lima) sertifikat tanah, jika memiliki lebih dari batas tersebut harus ada izin dari Kepala Kantor Pertanahan.

Setelah selesai pencatatan pada Daftar Isian 204, dilanjutkan oleh petugas untuk pemeriksaan sertifikat dan pencatatan di buku tanah dan sertifikat mengenai peralihan hak atas tanah tersebut yang didasarkan atau berdasarkan atas surat keterangan waris dan surat pernyataan dari para ahli waris, sedangkan akta hibah tidak disebutkan di dalam pencatatan sertifikat karena di dalam surat keterangan waris dan surat pernyataan dari para ahli waris tersebut sudah cukup kuat terkandung makna dari hibah wasiat. Oleh karena itu tidak perlu lagi dicatat mengenai hibah wasiatnya.

Setelah pencatatan di buku tanah dan sertifikat kemudian diparaf oleh Kepala Sub Seksi Peralihan Hak dan Pembebanan Hak (PHPH), selanjutnya permohonan peralihan hak tersebut diserahkan kepada Kepala Seksi Pengukuran dan Pendaftaran untuk diperiksa dan diparaf yang kemudian disampaikan kepada Kepala Kantor Pertanahan untuk ditanda tangani.
Jika sertifikat telah ditandatangani oleh Kepala Kantor Pertanahan, maka kemudian dilakukan pencatatan pada Daftar Isian 208 yaitu daftar tentang pembukuan sertifikat tanah. Kemudian sertifikat tersebut diserahkan kepada pemohon dengan terlebih dahulu menandatangani buku tanda terima penyerahan sertifikat yaitu Daftar Isian $301 \mathrm{~A}$.

Dari uraian tentang tatacara pendaftaran atau pencatatan peralihan hak atas tanah sudah sesuai dengan ketentuan Pasal 105 ayat (1) Permeneg Agraria nomor 3 tahun 1997. Di dalam standar prosedure operasional pengaturan dan pelayanan pertanahan di Kantor Pertanahan tidak ada pendaftaran peralihan hak karena hibah wasiat, yang ada hanya pendaftaran peralihan hak karena pewarisan dan peralihan hak karena hibah dan laon lainya. Untuk pendaftaran peralihan hak karena hibah wasiat. berdasarkan akta notaries, maka pendaftaran peralihan haknya dilakukan sama dengan pendaftaran peralihan hak karena pewarisan yaitu didasarkan atas surat keterangan waris dan surat pernyataan ahli waris, sedangkan akta hibah wasiat dari notaries fungsinya hanya digunakan sebagai dasar penunjukan subyek haknya saja. Jadi tidak dibuatkan lagi akta hibah wasiat di hadapan PPAT jika menurut penilaian Kepala Kantor Pertanahan dasar peralihan haknya sudah cukup kuat. Akan tetapi jika akta hibah wasiat hanya dibuat di bawah tangan dan Kepala Kantor Pertanahan meragukan kebenaran akta tersebut, maka perlu disyaratkan harus ada akta hibah yang dibuat dihadapan PPAT antara penerima hibah wasiat dengan pelaksana wasiat. Dengan demikian 
berarti di Kota Bandar Lampung Kepala Kantor Pertanahan berperan mengambil kebijakan menentukan perlu atau tidaknya dibuatkan akta hibah dihadapan PPAT antara pelaksana wasiat dengan penerima hibah wasiat.

\section{PENUTUP}

\subsection{Simpulan}

1. Jika memperhatikan ketentuan Pasal 112 ayat (1) Peraturan Menteri Negara Agraria/Kepala Badan Pertanahan Nasional tentang Ketentuan Pelaksana Peraturan Pemerintah Nomor 24 tahun 1997, bahwa peralihan hak karena hibah wasiat, tergolong peralihan hak karena pewarisan. Akan tetapi jika berdasarkan alat bukti peralihan, yaitu adanya alternatif pilihan alat bukti peralihan hak yang dapat dipakai sebagai dasar pendaftaran hak, berarti mengakibatkan dapat melalui SPOPP pewarisan dan dapat melalui SPOPP pemindahan hak yaitu hibah. Hal ini seperti tercamtum pada Pasal 112 ayat (1) angka 3 huruf $b$ dan c Peraturan Kepala BPN Nomor 3 tahun 1997, walaupun jika kalau dilihat dari waktu peralihan termasuk pewarisan. Tergolong peralihan hak karena pemindahan hak dalam hal ini hibah, apabila alat bukti peralihan haknya berupa Akta PPAT mengenai hibah yang dilakukan oleh pelaksana wasiat yang telah ditetapkan. Pendaftaran peralihan hak karena hibah wasiat tergolong peralihan hak karena pemindahan hak melalui hibah, jika alat bukti pemberian hak baik akta di bawah tangan maupun akta hibah wasiat yang dibuat notaris, menurut penilaian Kepala Kantor Pertanahan isi akta pemberian hak karena hibah wasiat tersebut kurang dipercaya atau meragukan. Dengan demikian berarti terhadap pendaftaran peralihan hak karena hibah wasiat, Kepala Kantor Pertanahan dapat melakukan kebijakan dalam penentuan alat bukti peralihan hak yang akan dipakai sebagai dasar dalam pendaftaran tanah karena hibah wasiat. Alat bukti peralihan hak akan menentukan Standar Prosedure Operasi Pengaturan dan Pelayanan yang akan dipakai. Dalam penentuan alat bukti peralihan hak tergantung dari kepercayaan atau hasil penilaian Kepala Kantor Pertanahan akan nilai kebenaran akta pemberian hak karena hibah wasiat tersebut.

2. Dampak adanya kebijakan penilaian dalam penentuan alternatif pilihan prosedure, di salah satu pihak memang tidak ada kepastian prosedure, tetapi dilain pihak diharapkan untuk mempermudah kesederhaan prosedure dalam rangka mewujudkan azas sederhana dan azas terjangkau, namun tetap harus memperhatikan asas aman dalam pendaftaran tanah.

3. Sedangkan mengenai pencatatan pendaftaran peralihan hak kedalam daftar daftar pendaftaran tanah terhadap pendaftaran peralihan hak karena hibah wasiat dilaksanakan berdasarkan standar procedure operasi pengaturan dan pelayanan pemindahan hak.

3.2 Saran 
Diharapkan sebagai upaya untuk menunjang pembaharuan pembangunan dan pembinaan hukum dikalangan mayarakat perlu ada standar prosedure operasi pengaturan dan pelayanan yang pasti dan jelas tentang pendaftaran peralihan hak atas tanah karena hibah wasiat.

Diharapkan Kantor Pertanahan dalam menilai kebenaran alat bukti pemberian hak, baik akta hibah wasiat di bawah tangan atau yang dibuat oleh notaris, sebagai dasar penentuan alat bukti peralihan hak berusaha mewujutkan kesederhanaan prosedure dalam arti tidak memberatkan masyarakat, alat bukti peralihan hak tidak perlu sampai berupa akta PPAT mengenai hibah, karena membuat akta hibah akan memperpanjang waktu dan menambah biaya, sedangkan penerima hibah wasiat belum tentu orang mampu ekonominya.

Diharapkan dalam memberikan penilaian alat bukti pemberian hak berusaha mewujudkan asas perlakukan yang sama atau asas persamaan yang berlaku bagi setiap orang.

\section{DAFTAR PUSTAKA}

Effendi, Bachtiar. Pendaftaran Tanah di Indonesia dan Peraturan Pelaksanaannya, Bandung: Alumni, 1983.

Harsono, Boedi. Sejarah Pembentukan UUPA, Isi dan Pelaksanaannya. Jambatan : Jakarta, 1999.

Agraria di Indonesia Himpunan Peraturan Hukum Tanah, jambatan : Jakarta, 2002.

Perangin, Effendi, Pertanyaan dan Jawaban tentang Hukum
Agraria. Rajawali : Jakarta, 1986.

Prawirohamijoyo, Soetejo. Hukum Waris. Rinta : Surabaya, 1984.

Pitlo, R. Hukum Waris Jilid 1. Internusa : Jakarta, 1986.

Suryo Pratiknyo, Hartono. Hukum Waris Testamenter, Universitas Gajah Mada : Yogyakarta, 1984.

Soedewi Macjchoen Sofwan, Sri. Hukum Perdata Hukum Benda. Liberty : Yogyakarta. 1984.

Subekti, R. Kitab Undang Undang Hukum Perdata. Paradnya Paramita. Jakarta : 1985.

Sayekti, Sri. Hukum Agraria Indonesia. Universitas Lampung : Bandar Lampung, 2000.

Saleh K, Wantjik. Hak Anda Atas Tanah. Jakarta : Ghalia Indonesia, 1997. ...Seri Perpajakan Pajak Bumi dan Bangunan. Jakarta : Sinar Grafika, 200

Undang Undang Nomor 5 Tahun 1960 tentang Peraturan Dasar Pokok Pokok Agraria

Undang Undang Nomor 30 tahun 2004 tentang Notaries

Peraturan Kepala Badan Pertanahan Nasional nomor 3 tahun 1997 tentang Peraturan Pelaksanaan PP Nomor 24 tahun 1997

Peraturan Kepala Badan Pertanahan Nasional Nomor 1 tahun 2005 Tentang Standar Prosedure Operasi Pengaturan dan Pelayanan di Lingkungan Badan Pertanahan Nasional 